\title{
Paideusis
}

\section{Border Crossings: Dialogue Across and Within Fields and Traditions}

\section{Daniel Vokey}

Volume 19, Number 1, 2010

URI: https://id.erudit.org/iderudit/1072325ar

DOI: https://doi.org/10.7202/1072325ar

See table of contents

Publisher(s)

Canadian Philosophy of Education Society

ISSN

0838-4517 (print)

1916-0348 (digital)

Explore this journal

Cite this article

Vokey, D. (2010). Border Crossings: Dialogue Across and Within Fields and Traditions. Paideusis, 19(1), 69-76. https://doi.org/10.7202/1072325ar
Article abstract

Drawing upon the work of Chantal Mouffe, Alasdair MacIntyre, and Bernard Lonergan, in this paper I develop an argument that, in our work as philosophers of education, we should support a particular form of what Ernst Boyer has termed the scholarship of integration, in part by being explicit both about the tradition(s) of inquiry in which we are working and about the nature of the particular contribution(s) we hope to make to those traditions. It offers five reasons why we should support systematic, sympathetic, agreement-oriented assessments of competing worldviews and corresponding ways of life. It advocates two kinds of "border crossings" as integral to such assessment: engagement across disciplines and fields on the one hand, engagement with rival paradigms within a discipline or field on the other.
This document is protected by copyright law. Use of the services of Erudit (including reproduction) is subject to its terms and conditions, which can be viewed online.

https://apropos.erudit.org/en/users/policy-on-use/ 


\title{
Border Crossings: Dialogue Across and Within Fields and Traditions
}

\author{
DANIEL VOKEY \\ University of British Columbia, Canada
}

\begin{abstract}
Drawing upon the work of Chantal Mouffe, Alasdair MacIntyre, and Bernard Lonergan, in this paper I develop an argument that, in our work as philosophers of education, we should support a particular form of what Ernst Boyer has termed the scholarship of integration, in part by being explicit both about the tradition(s) of inquiry in which we are working and about the nature of the particular contribution(s) we hope to make to those traditions. It offers five reasons why we should support systematic, sympathetic, agreement-oriented assessments of competing worldviews and corresponding ways of life. It advocates two kinds of "border crossings" as integral to such assessment: engagement across disciplines and fields on the one hand, engagement with rival paradigms within a discipline or field on the other.
\end{abstract}

\section{Introduction}

In what follows I will develop an argument that, in our work as philosophers of education, we should support a particular form of what Ernst Boyer has termed the scholarship of integration, ${ }^{1}$ in part by being explicit both about the tradition(s) of inquiry in which we are working and about the nature of the particular contribution(s) we hope to make to those traditions. I begin with two concerns raised by Paul Standish in response to a question posed to him by Anna Strahan, namely "How have you seen the discipline of philosophy of education change during the period that you've been involved with it?"

\begin{abstract}
If you are asking about the substance of philosophy of education, one of the things that has accompanied the growth of the last 20 years has been a broadening of the field and the incorporation of different traditions of inquiry and different approaches. For the most part, I think that's a good thing. The disadvantage is where you have a kind of Babel: lots of people talking in different voices and not being able to understand one another. That's obviously a very exaggerated description, but it is a danger. Another description that I'm more concerned about is where people write about topics but don't have any real sense of the tradition of that topic and there is no literature upon which they draw. I think it is desirable that people embed what they're writing in a tradition of inquiry. In education research more generally, I think that the failure to embed discussion within traditions is a much more serious problem. ${ }^{2}$
\end{abstract}

\footnotetext{
${ }^{1}$ Ernst Boyer, "Scholarly Work: New Definitions and Directions," in Creating Powerful Thinking in Teachers and Students, ed. J. N. Mangieri and C. C. Block (Fort Worth, TX: Harcourt Brace, 1994).

2 Anna Strahan, "An Interview with Professor Paul Standish," in Philosophy of Education Society of Great Britain Newsletter December 2007, ed. Nadine Cartner (London: PESGB, 2007), 13.

(C) Copyright 2010. The author, Daniel Vokey, assigns to Paideusis the right of first publication and educational and non-profit institutions a non-exclusive license to use this document for personal use and in courses of instruction provided that the article is used in full and this copyright statement is reproduced. Any other usage is probibited without the express permission of the author.
} 
I interpret Standish's second concern, that we are too often losing sight of the history of our discussions and debates, in light of my reading of Alasdair MacIntyre's account of the rationality of traditions. ${ }^{3}$ I think MacIntyre is right when he claims that all productive forms of inquiry presuppose the assumptions shared within and constitutive of a community of inquiry, which is the embodiment at a particular point in time of a tradition of inquiry. Thomas Kuhn has made a similar point, of course, in describing the roles played in science by paradigms of inquiry, here meaning the distinct sets of agreements—-some explicit, some tacit—by which rival communities of scientific inquiry within a field or discipline are differentiated. ${ }^{4}$ Rival communities typically use distinct technical languages, and differ on such matters as what kinds of questions and problems are important to address and what kinds of reasoning and evidence counts in providing answers and solutions.

According to MacIntyre, the norms and assumptions governing inquiry within a particular community, including that community's standards of rational judgment, are vindicated dialectically and historically. That is to say, allegiance to a paradigm is defensible to the extent that it has provided and continues to provide the conceptual resources necessary to respond successfully to epistemological crises better than existing alternatives. An epistemological crisis arises when key agreements shared within a community are called into question, in whole or in part, "sometimes by being challenged from some alternative point of view, sometimes because of an incoherence identified in the beliefs, sometimes because of a discovered resourcelessness in the face of some theoretical or practical problem, sometimes by some combination of these." ${ }_{5}$ The crisis is resolved when members of the community are able to reformulate their shared "scheme of beliefs" in a way that meets the following three criteria:

First, this in some ways radically new and conceptually enriched scheme, if it is to put an end to the epistemological crisis, must furnish a solution to the problems which had previously proved intractable in a systematic and coherent way. Second, it must also provide an explanation of just what it was which rendered the tradition, before it had acquired these new resources, sterile or incoherent or both. And third, these first two tasks must be carried out in a way which exbibits some fundamental continuity of the new conceptual and theoretical structures with the shared beliefs in terms of which the tradition of enquiry had been defined up to this point. ${ }^{6}$

Attention to a tradition of inquiry's history is important not just because those ignorant of the past risk repeating its mistakes. If MacIntyre is right, unless they are familiar with and can participate in the bistory of the debates through which their scheme of beliefs has been formed, members of a community of inquiry cannot contribute to the development of the corresponding tradition through creative responses to epistemological crises. Accordingly, I am inclined to agree with Standish that any sign of loss of historical memory in a community of inquiry, philosophical or otherwise, is legitimate cause for concern.

The second worry expressed by Standish is over a potential downside of paradigm proliferation within a field; that is, a "kind of Babel" created by "lots of people talking in different voices and not being able to understand one another."' Difficulties in communicating across paradigms is to be

\footnotetext{
3 Alasdair MacIntyre, After Virtue, 2nd ed. (Notre Dame: University of Notre Dame Press, 1984); Whose Justice? Which Rationality? (Notre Dame: University of Notre Dame Press, 1988); and Three Rival Versions of Moral Enquiry: Encyclopaedia, Genealogy, Tradition (Notre Dame: University of Notre Dame Press, 1990).

${ }_{4}$ Thomas Kuhn, The Structure of Scientific Revolutions (Chicago: University of Chicago Press, 1962) and The Essential

Tension: Selected Studies in Scientific Tradition and Change (Chicago: University of Chicago Press, 1977).

${ }_{5}^{5}$ MacIntyre, Three Rival Versions, 116.

${ }^{6}$ MacIntyre, Whose Justice?, 362 (italics added).

7 On "new" approaches to scholarship within philosophy of education that depart in significant ways from conceptual analysis, see (e.g.) Nigel Blake, Paul Smeyers, Richard Smith, and Paul Standish, eds., The Blackwell Guide to the Philosophy of Education (Oxford: Blackwell, 2003) 1-17; Nicholas Burbules, "Philosophy of Education," in Routledge International Companion to Education, eds. B. Moon, M. Ben-Peretz, and S. Brown (New York: Routledge,
} 
expected because, as noted above, rival conceptual schemes are characterized by some degree both of incommensurablility of meaning (key terms in one paradigm have no equivalent in another, rendering translation partial at best) and of incommensurability of standards (forms of argument and kinds of evidence convincing to those in one paradigm carry no weight with those in the other). Accordingly, a growth in the number of different approaches to inquiry within a field can result in more and more conversations, but each one involving fewer and fewer participants. The kind of fragmentation arising from a multiplicity of conceptions of/approaches to a field of inquiry can be compounded by the kind of push to specialization that Standish observes in philosophy departments in England under the research assessment regime.

A variety of different conversations and different forms of inquiry, philosophical and otherwise, are desirable inside as well as outside academia, particularly when that diversity includes the voices of those who previously have been denied opportunities to speak. For the benefits of such diversity to be fully realized, however, we cannot be content always just to talk to those who share our assumptions, technical languages, and concerns. Like Standish, I am interested in "crossovers between traditions," because it is "in connections between them and in frictions between them as well" that new ideas and ways of thinking are generated. ${ }^{8}$

Although it might not hold in all cases, a distinction can be made between two kinds of "border crossings": engagement across disciplines and fields on the one hand, engagement with rival paradigms within a discipline or field on the other. It is the former kind that Ernst Boyer advocates in recommending the scholarship of integration, in which new insights are generated by making connections among discoveries across a wide variety of forms of inquiry. According to Boyer, universities should undertake the scholarship of integration alongside the scholarships of discovery, of application, and of teaching to fulfill two responsibilities. The first is to address the urgent environmental, technological, and social problems facing the planet in the $21^{\text {st }}$ century, as the reality of interdependence is becoming more and more dangerous to ignore. The second is to help students gain "a coherent view of knowledge" in part by locating disciplinary discourses in "historical, social, and ethical perspective." Support for inter-, multi-, and transdisciplinary research is perhaps more common now than when Boyer first championed integrative scholarship. Where I think Boyer's recommendations still stand out is in foregrounding the ethical among the aesthetic, empirical, historical, and social dimensions of inquiry. ${ }^{10}$ We who study and teach in universities cannot fulfill our responsibilities without confronting the ethical questions related to our work, and this holds regardless of the particular disciplines, fields, or faculties in which that work is located.

In proposing that philosophers of education should support the scholarship of integration that Boyer recommends, I have a particular form of "big picture" thinking in mind, one that fits well with his emphasis upon ethics. What I recommend we support is systematic, sympathetic assessments of the strengths and limitations of alternative worldviews and their corresponding ways of life, undertaken with the intent to enlarge understanding and agreement among those whose moral points of view now conflict. Let me first explain what I mean by this and then say why I think it is important.

As I use the term, a worldview is a set of beliefs about the fundamental nature of things, including the origin, history, and structure of the cosmos; the kinds of objects that exist in the world; the kinds of

2000), 3-18; David Ericson, "Philosophical Issues in Education," in Encyclopedia of Educational Research, ed. M. Alkin (New York: Macmillan,1992), 1002-1007; and Wendy Kohli, "Educational Theory in the Eighties: Diversity and Divergence," Educational Theory 50, no. 3 (2000): 339-356.

${ }^{8}$ Strahan, "An Interview," 13 (italics added).

${ }^{9}$ Boyer, "Scholarly Work,"189-190.

${ }^{10}$ Boyer, "Scholarly Work," 191. Kai Chan "NBT: A New Way to Assess Local Ecosystems Sustainability," UBC Reports 54, no. 1 (2008): 4 describes integrated work of the kind I think Boyer has in mind: "The study of ecosystem services brings together experts from ecology, economics, conservation, hydrology, anthropology, earth and ocean sciences, ethics, and more to provide as complete a picture as possible of the potential pros and cons of management decisions facing ecosystems." 
relationships that hold among those objects; and the nature of humans and their place in the world order. Together with associated images and root metaphors, these sets of beliefs typically form an unquestioned background to thought and action, subject to reconsideration only when an unexpected event or unusual circumstance calls them into question. I use the phrase way of life to refer to a particular constellation of attitudes, interests, norms, and priorities enacted in a community's, society's, or state's practices and institutions.

I understand the relationship between a worldview and a corresponding way of life as analogous to the relationship between the assumptions internal to a particular paradigm of inquiry-behavioural as opposed to humanistic or transpersonal psychology, for example-and the attitudes, interests, norms, priorities and practices of the corresponding community of inquiry. That relationship is not one of logical or causal necessity. Up to a point, different sets of beliefs about the world can be compatible with the same way of life, and the same set of beliefs can be compatible with different ways of life. For example, ways of life that prioritize the study and practice of biblical teachings have continued through changes in cosmological beliefs over the long history of Christian and other theistic traditions. This "looseness" of fit with worldviews notwithstanding, our overall ways of life typically shape and are shaped by our fundamental beliefs about the world such that each will not be radically at odds with the rest. There are two assertions here. The first is that how we spend our lives is connected to our basic assumptions about what exists, about what kinds of knowledge are possible and important, and about what makes some things morally right and others morally wrong. The second is that our basic ontological, epistemological, and normative beliefs tend to come as a package deal. As religious scholars have long observed, the links between ways of life and worldviews are traditionally made in stories that describe and/or illustrate what attitudes, interests, norms, and priorities make sense in light of particular views of the limitations and opportunities of human existence. ${ }^{11}$

I believe we should support agreement-oriented systematic assessments of competing worldviews and corresponding ways of life for the following five reasons. First, as I imagine most philosophers would agree, I think it makes a great deal of difference which images, metaphors, concepts, and explanatory frameworks mediate our experience and so shape how we perceive, feel, think, and act-individually and collectively. Consider how much ink has been spilled arguing the relative strengths and limitations of competing conceptions of critical thinking and corresponding program proposals. If it is important to have better rather than worse conceptual frameworks to inform particular educational practices, policy initiatives, and research projects, then surely it is at least equally if not more important to have better rather than worse sets of basic ontological, epistemological, and normative assumptions to inform our overall ways of life.

Second, recent years have seen new developments in science that I believe have significant implications for our fundamental ontological, epistemological, and normative assumptions that in turn bear upon important issues within philosophy of education. For one example, there is the work by Brent Davis and Dennis Sumara on complexity thinking in which they develop the implications of new models of causality for philosophy of educational research. The critique they offer of the epistemological assumptions underlying the 2001 act No Child Left Behind is an excellent example of the danger of leaving metaphysical assumptions unexamined. ${ }^{12}$

Third, I believe that positions on specific topics within philosophy of education are often only fully intelligible and defensible when articulated in the context of a compatible worldview. One example of this is the literature proposing programs of moral education informed by Aristotelian or neoAristotelian virtue ethics. MacIntyre has recognized that, given the links between Aristotle's ethics and his belief in an innate human nature, contemporary advocates of this tradition must either rehabilitate

\footnotetext{
11 John D. Crossan, The Dark Interval (Niles, IL: Argus Communications, 1975); Peter Slater, The Dynamics of Religion (San Francisco: Harper and Row, 1978).

12 Brent Davis and Dennis Sumara, Complexity and Education: Inquiries into Teaching, Learning, and Research (Halwah, NJ: Lawrence Erlbaum, 2006), 37-38, 49-50.
} 
Aristotle's teleological worldview or furnish a defensible substitute. ${ }^{13}$ Zinaich makes a similar connection between ontological and normative commitments by arguing that, precisely because of difficulties with its metaphysics, attempts to restore virtue ethics should be abandoned. ${ }^{14}$ Of course, other traditions of moral inquiry and practice are vulnerable to similar critiques: advocates of the more substantive forms of Kantian deontological ethics require some explanation of what it is about humans (as distinct, perhaps, from other mammals) that makes them intrinsically worthy of respect.

Fourth, because the disagreements that profoundly divide us inside and across national boundaries are often rooted in and related to the differences between competing worldviews, I believe that efforts to reach enough agreement for just, peaceful, and sustainable ways of life must go equally as deep. I expect, I hope not too optimistically, that greater agreement on a worldview or set of reasonably compatible worldviews would contribute significantly to the resolution of many important moral disputes. The flip side of this position is my conviction that, given the existence of worldviews that are in some cases radically incompatible, the Rawlsian liberal strategy of prioritizing the right over the good is not an adequate response to the challenge that pluralism presents to liberal democratic states. ${ }^{15}$ Maintaining and re-creating systems of public schooling and higher education involve too many beliefs about what is and is not real, what kinds of knowledge are and are not important, and when it is and is not morally permissible to remain neutral between competing accounts of what it means to be a human being. Chantal Mouffe argues along similar lines when criticizing the "strong separation" between the public and private realms John Rawls seeks to legislate and the similar move by Jurgen Habermas to separate the "morality-domain" from the "ethics-domain." She warns that, by relegating pluralism to a "nonpublic domain" to avoid challenges to its fundamental assumptions from alternative standpoints, liberalism risks alienating citizens from the party-based political process. ${ }^{16}$ In the same vein, MacIntyre accuses the modern liberal university of having become "culturally irrelevant" (if not a servant of a repressive political status quo) by having "successfully excluded substantive moral and theological enquiry from its domain." 17 Such critiques need not be taken as rejecting all the beliefs and values that political liberals extol. Once we take pluralism as an opportunity for learning rather than a problem to avoid, identifying an overlapping consensus in particular social contexts can be appreciated as an excellent beginning to, not a substitute for, dialectical assessments of competing sets of core beliefs. ${ }^{18}$

Fifth and finally, the current state of world affairs leads me to believe that at least some of the core assumptions of "our" dominant mechanistic worldview are profoundly mistaken. ${ }^{19}$ This is not a new idea, of course. ${ }^{20} \mathrm{It}$ is implicit or explicit in the many calls for one or another form of transformative education, calls in which a radical change of heart and mind is seen as essential if we are to survive the social,

\footnotetext{
13 MacIntyre, After Virtue.

${ }^{14}$ Samuel Zinaich, Jr., "Returning to Virtue Theory: Some Problems and Challenges," Global Virtue Ethics Review 5, no. 4 (2004): 50-90.

${ }^{15}$ A favorite illustration of competing worldviews and their profound implications for practical judgment is the encounter between Abbot Zerchi and the agnostic doctor in Walter M. Miller Jr.'s A Canticle for Leibowitz. (New York: Bantam Books,1959), 270-276.

${ }^{16}$ Chantal Mouffe, Deliberative Democracy or Agonistic Pluralism (Vienna: IHS, 2000).

${ }^{17}$ MacIntyre, Three Rival Versions.

${ }_{18}$ Daniel Vokey, "MacIntyre and Rawls: Two Complementary Communitarians?" in Philosophy of Education 2002, ed. A. Alexander (Urbana, IL: Philosophy of Education Society, 2003), 336-341. For an illustration of how dialectical assessment might proceed, see Daniel Vokey, “Anything You Can Do I Can Do Better': Dialectical Argument in Philosophy of Education," Journal of Philosophy of Education 43, no. 3 (2009): 339-355; and Daniel Vokey, Moral Discourse in a Pluralistic World (Notre Dame: University of Notre Dame Press, 2001).

${ }^{19}$ Vokey, Moral Discourse, 88-92.

20 Richard Atleo's Tsawalk: A Nuu-chah-nulth Worldview (Vancouver: UBC Press, 2004) and Oscar Kawagley's Yupiaq Worldview: A Pathway to Ecology and Spirit (Prospect Heights, IL: Waveland Press, 1995) represent recent efforts, motivated by similar concerns, to re-articulate indigenous worldviews in the context of the domination of European worldviews.
} 
political, economic, environmental, moral, and/or spiritual crises that, depending upon our locations and perspectives, are seen to be darkening the horizon and/or already unravelling the fabric of life. ${ }^{21}$ Since calls for transformative change are not yet a harmonious chorus, systematic assessments of competing worldviews are needed to create greater agreement on: (a) what shifts in perceiving, feeling, thinking, and acting are most urgently required, (b) by whom (c) how they might be accomplished. This point applies to other forms of education as well. For example, I expect greater agreement on fundamental ontological, epistemological, and normative assumptions would also be required to reach agreement on what particular forms of national and global citizenship education will succeed in reasserting the priority of democracy and justice over market imperatives. ${ }^{22}$

To forestall one likely objection to my proposal, I should acknowledge that the project of systematically assessing competing worldviews and ways of life sounds similar to "traditional" conceptions of philosophy of education that have fallen out of favour. As John Portelli tells the story, the limitations and failures of traditional conceptions prepared the ground for the emergence of analytic philosophy of education as the dominant paradigm within the field. ${ }^{23}$ Is my recommendation consistent with postmodern suspicions of grand theorizing? How far should our distrust of metanarratives extend? How much background agreement and on what key issues is not only compatible with appreciating diversity, but also required to create and maintain social and global institutions within which diversity can flourish? To my mind, these questions underline rather than undermine the validity of the assessment project I propose. The same critical sociological analyses of unequal power relationships that prompt suspicion of efforts to produce moral consensus also reveal the dangers of leaving dominant worldviews and narratives unchallenged.

Would we be required to do philosophy of education very differently in order to support systematic assessments of competing worldviews and ways of life? As I think Boyer would agree, I believe the methods and results of all forms of inquiry-empirical, interpretive, conceptual, historical, normative, literary, arts-based, and more-have important roles to play in the scholarship of integration. I consider philosophy to be the natural home for much of the multidisciplinary and transdisciplinary work of assessing, not just particular claims and theoretical positions, but also the larger conceptual frameworks, root metaphors, metanarratives, and social contexts that they assume. Philosophy of education is well placed to contribute to such projects since it enjoys a front-row seat at the complex interplay of theory and practice and, as Standish observes, naturally gives rise to "big picture" thinking. What I am proposing is not so much that we undertake anything dramatically different from what we are already doing as that we be more explicit about the relationships between our work and the larger sets of assumptions and commitments that they presuppose. This would mean being explicit, in whatever ways and to whatever extent is appropriate to the task at hand, about the tradition or traditions of inquiry in which we locate our philosophical scholarship, as well as the other ways in which our work is "located." It would also mean being explicit about the nature of the particular contribution(s) we hope to make to those traditions.

My inspiration for the latter suggestion is Bernard Lonergan's account of "functional specializations" within theological "method," which illustrates how the efforts of specialists find their

${ }^{21}$ Edmund O'Sullivan, Transformative Learning: Educational Vision for the $21^{\text {st }}$ Century (Toronto: University of Toronto Press, 1999), 1-9, 259-281; Mike Seymour, Educating for Humanity: Retbinking the Purposes of Education (Boulder: Paradigm Publishers, 2004), 1-10.

22 Jennifer Chan-Tiberghien, "Towards a 'Global Educational Justice' Research Paradigm: Cognitive Justice, Decolonizing Methodologies and Critical Pedagogy," Globalization, Societies, and Education 2, no. 2 (2004): 191-212. Harvard University President Drew Faust very recently argued (http://www.president.harvard.edu/ speeches/faust/081014_hbs.html) that the current collapse of key financial systems testifies to the need to articulate a shared moral vision in order to locate individual aspirations within broader horizons, and to resist the growing pressure upon universities to serve only narrow economic ends.

${ }^{23}$ John Portelli, "Analytic Philosophy of Education: Development and Misconceptions," in Reason and Values: New Essays in Philosophy of Education eds. J. Portelli and S. Bailin (Calgary: Detselig Enterprises, 1993). 
full significance when understood as contributions to larger theological initiatives and debates. ${ }^{24}$ To transpose that account to philosophy of education, we could consider the range of possible contributions to ongoing initiatives within and debates between rival moral traditions and competing paradigms of moral education. Scholars working within, say, the Kohlbergian cognitive-developmental paradigm within the tradition of Kantian deontological ethics could undertake: to develop its theoretical framework by (a) improving its internal consistency, (b) unpacking its logical implications, and/or (c) illustrating its relevance to practical issues; to defend the Kohlbergian scheme in dialectical debates with rival conceptual frameworks such as the ethics of care; or to revise its assumptions in light of (a) practical successes and failures in achieving its educational objectives and/or (b) developments in relevant disciplines such as psychology and philosophy. A further step would be to show what the rise or decline of the paradigm implies for questions at the level of competing worldviews; such as whether or not attributions of individual agency are consistent with a relational view of persons, and whether or not moral commitments can be rationally redeemed.

Locating scholarly work in terms of specific contributions to particular paradigms that are themselves located within larger debates could go some way to redressing the fragmentation that can be a by-product of academic specialization. What about communication across rival paradigms within a discipline or field? I share MacIntyre's view that the incommensurability characterizing rival paradigms is not overcome by translation, but by those from one paradigm learning to appreciate the perspective of the other paradigm, analogous to a person learning to speak a foreign tongue as a "second first language." Supporting the project I recommend would thus include seeking opportunities to appreciate the worldviews and overall ways of life of people from other times and places as well as their more specific concepts and theories. ${ }^{25}$ Two final points on this idea. First, particularly where ethics is concerned, I believe that appreciating other traditions requires us to go deeply into our own. What is it that we most care about, and why? How might we help someone who does not share those commitments understand, intellectually and emotionally, what it means to embrace such ideals as equality and freedom?26 Second, our responsibility to engage with "the other" varies with the privileges we do and do not enjoy by virtue of our "social location(s)" in relationships of power. To give the last words to Mouffe: "... if we accept that relations of power are constitutive of the social, then the main question for democratic politics is . . how to constitute forms of power more compatible with democratic values." 27

\section{Acknowledgments}

An earlier and abbreviated version of this paper was presented at the Annual Conference of the Philosophy of Education Society of Australasia (PESA) at the East-West Center, Honolulu, Hawai'i, December 3 to 6, 2009. I am grateful to members of the audience, and to an anonymous reviewer of the original submission to Paideusis, for their questions, which identified elements of the paper that needed elaboration.

\footnotetext{
${ }^{24}$ Bernard J. F. Lonergan, Method in Theology 2nd ed. (London: Dartman, Longman, and Todd, 1973).

25 An example of such an opportunity is the symposium African Education: Worldviews, W ays of Knowing and Pedagogy held at the University of British Columbia, Vancouver, BC, November 24, 2006. For a relevant defense of the value of exposure to different cultures, see Sharon Bailin's 2006 Presidential Address, "Inquiry into Inquiry: (How) Can We Learn from Other Times and Places?" in Philosophy of Education 2006, ed. D. Vokey (Normal, IL: Philosophy of Education Society, 2007).

${ }^{26}$ For an attempt at the beginnings of an answer, see Vokey, Moral Discourse, 249-287.

${ }^{27}$ Mouffe, Deliberative Democracy, 14.
} 


\begin{abstract}
About the Author
Daniel Vokey is Associate Professor in the Faculty of Education at the University of British Columbia. Drawing upon his academic background in religious studies and in philosophy of education, his professional experience facilitating wilderness-based experiential education programs (Outward Bound), and his ongoing training in the contemplative pedagogies of Tibetan Buddhism, he investigates the theory and practice of teaching professional ethics for educators, the contributions of philosophy to educational research, and the relevance of teachings and practices from the world's wisdom traditions for transformative initiatives in higher education. Correspondence should be sent to daniel.vokey@ubc.ca.
\end{abstract}

